 \\ Research Article} \\ (C) 2020 Hellena Mohamedy Mushi. \\ This is an open access article licensed under the Creative Commons \\ Attribution-NonCommercial 4.o International License \\ (https://creativecommons.org/licenses/by-nc/4.0/)
}

Received: 16 May 2020 / Revised: 28 July 2020 / Accepted: 29 July 2020 / Published: 23 September 2020

\title{
Intention, Government Regulation, Self-Regulatory Efficacy, Subjective Norm, Idolatry and Consumer Behaviour in Purchasing Pirated Compact Disks (CDs) in Mainland Tanzania
}

\author{
Dr. Hellena Mohamedy Mushi \\ Mzumbe University, Mbeya Campus College, \\ P.o.Box 6559 Mbeya, Tanzania
}

DOI: https://doi.org/10.36941/mjss-2020-0050

\section{Abstract}

This study is conducted to explore the factors influencing purchase behaviour and to explain the magnitude of such factors on buying behaviour in Tanzania. Based on a systematic review of literature, a research framework was developed from Theory of Planned Behaviour (TPB). The casual model was empirically tested by using partial least-square structural equation modelling (PLS-SEM). The survey is comprised of 491 usable samples, collected from Generation Y consumers as the main music users in Tanzania. Result suggest that the model is significant and adequate. All antecedents of intention appears to be significant except for idolatry. Selfregulatory efficacy and subjective norm are contributing factors to intention construct. Intention, along with self-regulatory efficacy is found to have significant impact on consumer buying behaviour. Government Regulation is found to have non- significant moderating impacts on the relationship between intention and consumer buying behaviour. In addition to theoretical implication, a number of managerial implications are observed. Marketers need to enhance consumers buying behaviour in various stakeholders, reduce music piracy through motivation on self-regulatory efficacy and subjective norm to Generation Y. Overall, the study is expected to confer value to music industry through discourage music piracy by researchers and marketers.

Keywords: consumer buying behaviour, intention, government regulation, self-regulatory efficacy, idolatry and subjective norm

\section{Introduction}

Due to the increase volume of sales of pirated music CDs nowadays in the world Pehrsson \& Sattari (2015), especially in Tanzania, the causes for increase of purchase of pirated CDs in Tanzania have not been investigated empirically. Few empirical studies have so far investigated the increase level of pirated CDs purchase in Tanzania (Mushi, 2016) so by understanding consumer behaviour towards purchases of pirated music CDs, as in finding answers to questions like "how do they buy?, " who buys?", and "why do they buy?" is a step in the accurate direction (Charron, 2015) .Certain practical issues that are influence Gen Y to purchase pirated music CDs may be grouped into three different factors. They are: availability, price issues and technology. It was observed that due to high demand of the non-pirated music CDs in the market but the shortage of supply this leads customer to purchase pirated music CDs while waiting for original one (Nova, Rahayu, \& Handayani, 2015) Price also is one factor which leads consumer especially Generation Y to turn into pirated music CDs and sometimes consumers failed to afford, in Tanzania the original CDs is $90 \%$ higher prices than the 
pirated music CDs, the cost of pirated music CDs could be less than the original one so counterfeiter sale more and gain more profits (Waldfogel, 2012). The rapid speed of technology advancement enhance the all Generation Y rank to acquire the information quickly. Thus, encourage the mass production of pirated music CDs that could be resembled with authentic music CDs Arli, Tjiptono, \& Porto, (2015). Therefore, it remains to see as to what extent these issues are influencing consumer's intention and consumer buying behaviour in pirated music CDs.

\section{Literature Review}

In order to understand the factors influence consumer intention to buy pirated music CDs and consumer buying behaviour, a number of theoretical framework have been suggested and tested, among which the Theory of Reasoned Action and its later modified Theory of planned Behaviour have been found to be widely used in recent studies (Arli et al., 2015; Kiksen, 2012; Li, Miller, \& Ruiz, 2014; Reardon, Reardon, \& Vida, 2012) Theoretically, "purchase intention" has been used by most researchers as a predictor for purchase behaviour, based on the Theory of Planned Behaviour (Ajzen \& Fishbein, 1980) It was observed that not many studies focused on consumer buying behaviour. This has also been the case for studying consumer buying behaviour in Tanzania context.

\subsection{Purchase Behaviour}

Previous scholars finding consumer's intention to purchase pirated music CDs and consumer buying behaviour, inconsistency has been observed in the intention-behaviour relationship (Fetscherin, 2009; Lalović et al., 2012; Ouellet, 2007). Consequently, many authors have suggested use of other factors to explain this gap (Chiou et al., 2005; Cuadrado, et al., 2009; Halttunen et al., 2010; Plowman \& Goode, 2009). Ajzen \& Fishbein, (1980) contend that not all the intentions can be transformed into actual behaviour though there are correspondence between measures of intentions and behaviour. Nevertheless, there are some factors which can change the intentions over time such as new technology, unexpected circumstances such as injury, illness, financial constraints, job loss and family matters (Ajzen, 1985). Unluckily, many researchers who deals with unethical behaviour to examine music piracy behaviour by using TPB anticipated that intentions are good measure of actual behaviour and still yet ignored to measure the actual behaviour such as Bashir, Phau, \& Ferguson, (2012) Definitely, Kiksen et al., (2012) renowned that most studies do not measure the actual behaviour this was observed through their study. Therefore, further studies are warranted to investigate the intention- behaviour gap.

\subsection{Intention}

Studies have shown that not all the time intentions can be transformed into actual behaviour Nevertheless, there are some factors which can change the intentions over time such as new technology, unexpected circumstances such as injury, illness, financial constraints, job loss and family matters (Ajzen, 1985). Unluckily, many researchers examine music piracy behaviour by using Theory of Planned Behaviour anticipated that intentions are good measure of actual behaviour and still yet ignored to measure the actual behaviour (Jesse, 2015). This consumer intention-behaviour gap' with respect to ethical issues has been noted by several researchers (Coyle et al., 2009; Huang et al., 2015; Lin et al., 2015; Tat et al., 2012; Van Belle, Macdonald, \& Wilson, 2014). Based on the above discussion, the following hypothesis is hereby proposed:

H1: Purchase intention is positively related to purchase behavior of pirated music CDs

\subsection{Government regulations}

A number of previous studies identified government regulations can be important solutions to piracy (Bikoff, Heasley, Sherman, \& Stipelman, 2015; Eisenberg \& Dhabi, 2015; Khadka, 2015). In this study 
government regulations has been used as a moderator between purchase intention and consumer buying behaviour, also government regulation divided into two dimension: government enforcement and government support. Enforcement implies the act of compelling observance of or compliance with a law, rule or obligation (Oxford University Press, 2014).Government support in this study refers to the assistance rendered by the authority to discourage the purchases of pirated music CDs within the music industry (Oxford University Press, 2014). Still, not many studies were done on the intention-behaviour gap to explain this variable.

In addition, Tanzania, has not been active like in other African countries, in promoting reforms towards the development of the music sector (Shule,2010). Government support tends more often than not tends to be directed to management activities and administrative rather than to production activities and enabling environment in support of implementation (Kajiru,2009). Young people have been noted that comprise majority of the population in Tanzanian social cohesion which is highly valued and contributing to the economy. According to the National Art Council (BASATA), there are about six million Tanzanians who belong to the creative sector (Buitrago \& Mo, 2009, p 6). This is about $15 \%$ of the total population. It cannot be denied with such a figure, the government needs to pay serious consideration to this percentage of its population. If creative arts, can bring political and social change such as the theatre, then creative industries, particularly music, if well developed, can bring about economic change as well (Shule,2010). It is clear that based on these evidences, the government's lack of support to the music industry leads consumers to purchase many pirated CDs, and some of the musicians even surrender their works to these illegal distributors, which increases the sale of pirated CDs (Makulilo \& Boshe, 2013). Based on the above discussion, the following hypothesis is hereby proposed:

H2: Government regulation moderates the relationship between intention to purchase pirated CDs and consumer purchasing of pirated CDs in Tanzania

\subsection{Self- regulatory efficacy}

Self- regulatory efficacy is considered to be a vital factor in explaining consumer buying behaviour more concretely. In relation to music piracy, previous studies on consumer behaviour suggest that self- regulatory efficacy is one of the important factors that influences consumer buying behaviour (Baumeister et al., 2008; Caprara et al. (2002); LaRose \& Kim, 2007; Sultan et al., 2012). Yet selfregulatory efficacy seems to be understurdied in purchases of pirated music CDs so far. Infanct, only few studies can be traced that studied self-regulatory in the consumer buying behaviour context , therefore warranting a systematic study in this respect

H3: Self-regulatory efficacy has a positive relationship with actual purchase of pirated CDs in Tanzania

Self-regulatory efficacy supports its significant relationship with consumer intentions to purchase counterfeit products ( Fennis et al., 2009; Larose et al., 2001; LaRose \& Kim, 2007; Oaten \& Cheng, 2006; Vohs \& Faber, 2007). According to LaRose \& Kim (2007) in their study they found that deficient self-regulatory efficacy to have a positive significant with the intention . A similar contention was made by Oaten \& Cheng (2006), who stated that every major personal and social problem has some degree of regulatory failure. The idea that the capacity for self-regulation can be improved is therefore of vast practical importance so he found positive relationship between selfregulatory efficacy and intention. Other studies by Vohs \& Faber (2007) of the same calibre showed that self-regulatory and intention have a significant positive relationship. Participants whose resources were depleted, relative to participants whose resources were not depleted, felt stronger urges to buy, were willing to spend more, and actually did spend more money in unanticipated buying situations.

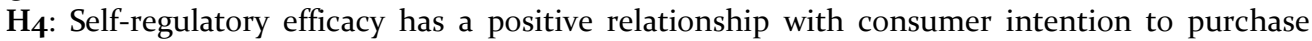
pirated music CDs in Tanzania. 


\subsection{Subjective Norm}

Based on Theory of Planned Behaviour, subjective norm appears to be another important predictor of purchase intention. According to Lapinski \& Rimal (2005), a composition of injunctive norm and descriptive norm can be viewed as subjective norm. Most researchers it appears that used injunctive norm as a proxy to subjective norm, neglect descriptive norm understudied (Hardy et al., 2013). Hence, in the case of purchases of pirated music CDs studies, integrated effect of both types of norms appears to be understudied. Although some findings from the marketing literature were contradictory, many studies reported that subjective norms or social influences are crucial in describing the relationship between intention and behaviour (Bashir et al., 2012; Kiksen, 2012; Lin et al., 2013; Reardon et al., 2012), and act as antecedent for behavioural intention (Blake \& Kyper, 2011; d'Astous et al, 2005; Plowman \& Goode, 2009; Setiawan \& Tjiptono, 2013; Wang et al., 2009). Even though numerous studies had been carried out to examine the linkage between subjective norm and consumer behavioural intention, unfortunately the results produced were inconsistent. This suggests that more research is required to establish the relationship between subjective norm and intention to purchase pirated music CDs. Furthermore, in response to Cronan and Al-Rafee (2008) suggestion, although research on subjective norm is diverse, limited studies were conducted in the African context. They suggested that further study should be conducted to fill this void. This study therefore fills this gap by further investigating subjective norm as a potential factor that influences intention to purchase pirated music CDs. Based on the above discussion, the following hypothesis is hereby proposed:

H5: Subjective norms have a positive relationship with intention to purchase pirated CDs in Tanzania

\subsection{Idolatry}

Many past studies also emphasized idolatry as an influencing factor on purchase intention of pirated music CDs (Chiou et al., 2005; Einerson, 1998; Kiksen et al., 2012; Ouellet, 2007; Raviv, Bar-Tal, Raviv, \& Ben-Horin, 1996; Wang, Chen, Yang, \& Farn, 2009; Yue, Cheung, \& Wong, 2010). However, evidence from other behavioural studies has suggested that idolatry stimulate people to buy music and interfere with an individual's behaviour and commitment (Hyman \& Sierra, 2010; Yue et al., 2010). However, contradictory findings were also reported on the impact of idolatry on the relationship between behavioural intention and behaviour by Wang et al. (2015) found the negative relationship between idolatry and intention. Idol worship has changed due to may be the consumers' attitude. Through buying the singers' album CD isn't necessary their behavior of worship. To enjoy their idols' music can be through other informal ways. Thus the conflicting results warrant further investigation on relationship between idolatry and purchase intention.Therefore, the following hypothesis is developed:

H6: Idolatry has a positive relationship to intention to purchase pirated CDs in Tanzania.

Based on the above discussions, the following conceptual framework is presented:

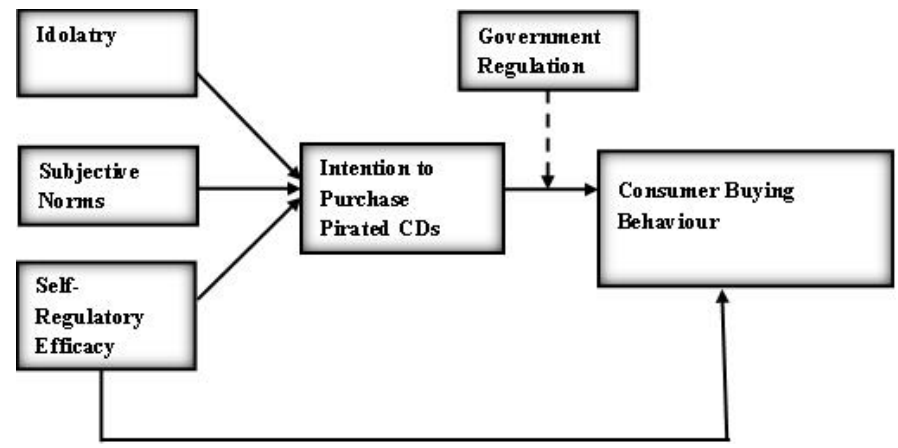

Fig. 1. Conceptual Framework 


\section{Research Methods}

To achieve this study's objectives a combination of inferential and descriptive statistics were employed as data analysis methods. As explained in the research design earlier, describing characteristics of people, organisations, objects, groups, or environment and explanation of one variable relationship to another deals with descriptive statistics. When a researcher draw conclusions (or to make inferences) from a sample refers to inferential statistics .In this study, two major PLS SEM software applications however, a combination (Ringle, Wende, \& Will, 2005) and PLS-Graph (Chin et al.,2003) in the analysis and result presentation were employed.

\section{Result}

The data applied for this study was retrieved by assigning 800 questionnaires to Tanzanian Generation Y consumers, out of which 491 were usable for the analysis, representing $67.5 \%$ of the population. This study applied the PLS approach to examine the research questions. The structural model were used to distinguished the significant path relationships between factors involved in influencing consumer buying behaviour among the Tanzanian users of pirated music. For decision making one tailed (o.01, 0.05 and o.1) level of significance was applied relating to the hypotheses.

\subsection{Measurement Model Evaluation}

Individual item reliability internal consistency of reliability, content validity, discriminant validity and convergent validity can be evaluated and determined in measurement model (Hair et al., 2014; Hair et al., 2011; Henseler et al., 2009).

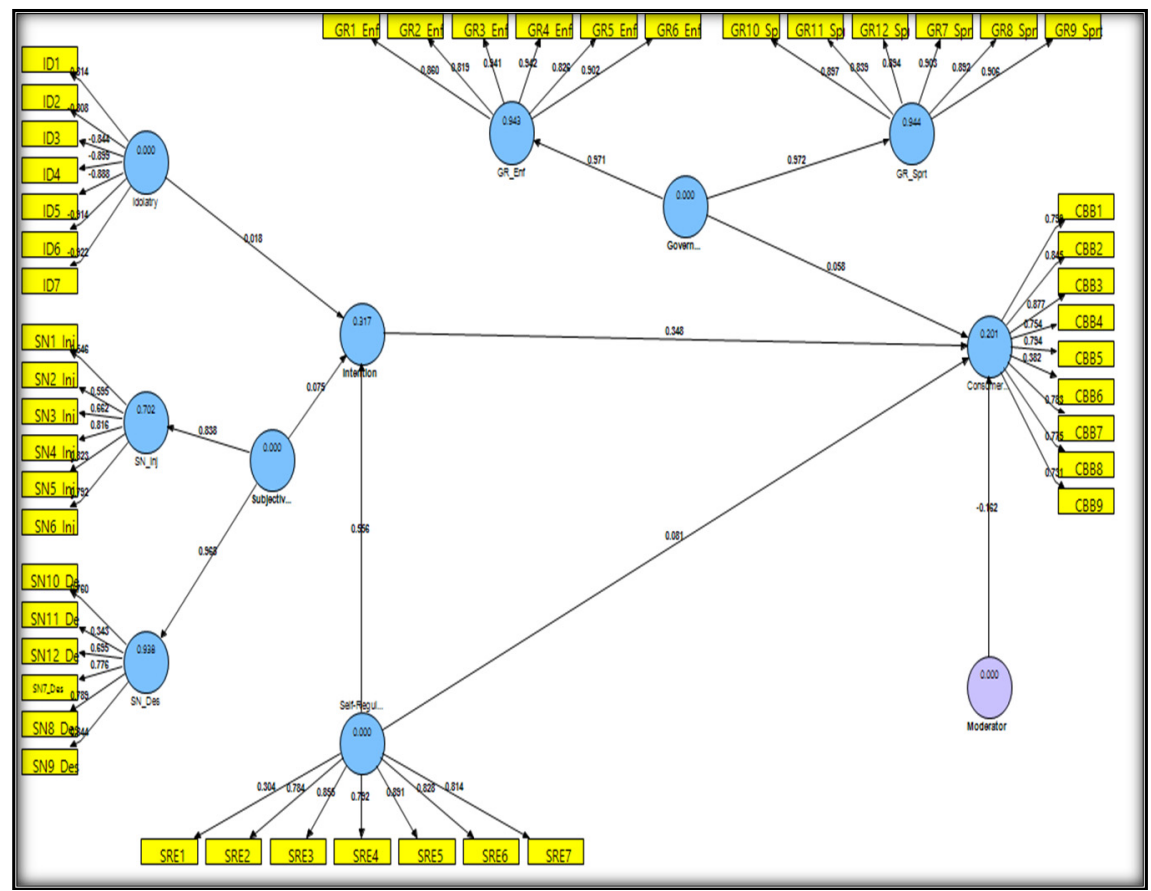

Figure 2: Measurement Model 


\subsection{Assessment of Significance of the Structural Model}

In this study the outer model veracity is ascertained here, the structural model assessment, and the establishment of the relationship between latent variables (constructs). To assess the significance of the path coefficients this study applied bootstrapping procedure with 5000 bootstrap samples and 491 as a base of the nonparametric evaluation criteria (Hair et al., 2012; Hair et al., 2014, Hair et al. 2011; Henseler et al., 2009) The structual (inner) model, in this study, and moderating effects inclusion are depicted in In Figure 3.

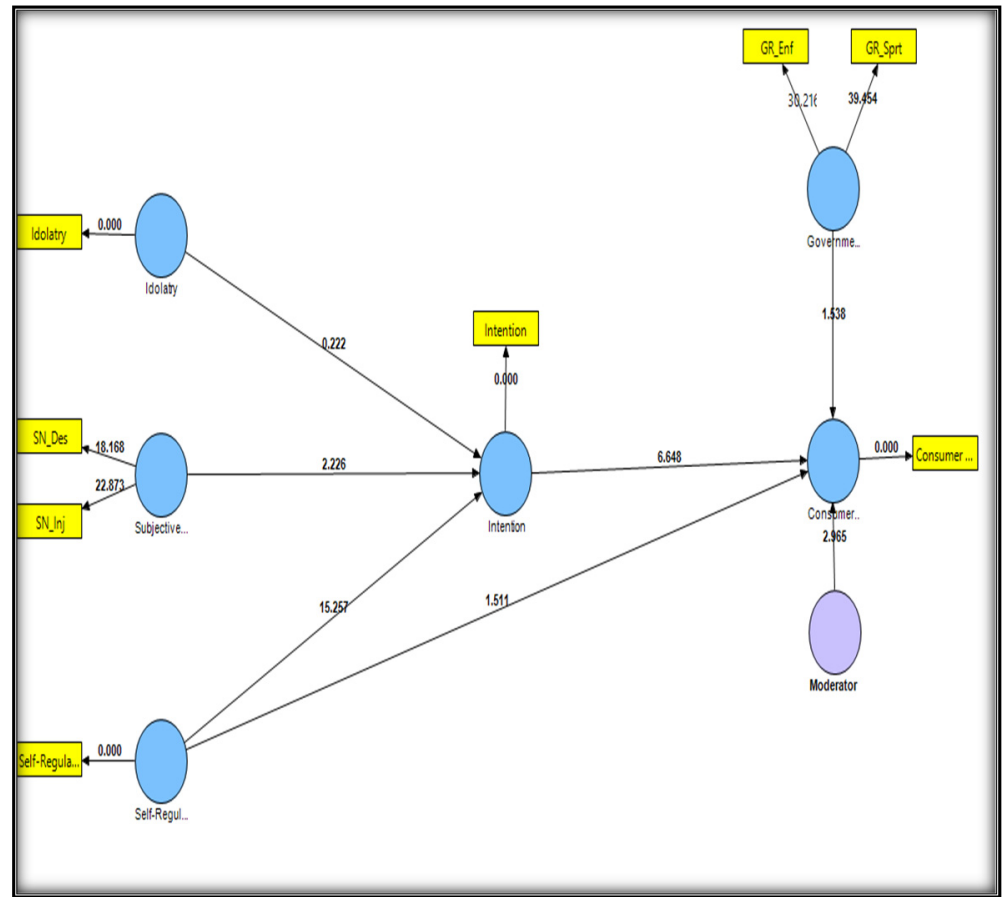

Figure 3: Structural Model with Moderator (Full Model)

Equally, the moderating variable, which is government regulation and the estimates for the full structural model shown in Table 1. The full model (including the moderating effect) assessment shown on Table 1. Originally, intention is positively related to consumer buying behaviour as it was predicted in hypothesis 1 . The execution of the buying behaviour will be improved when a consumer exhibits the strong intention to purchase pirated music CDs, this is indicated by the result in Table 1. By implication, consumer intention in purchasing pirated music CDs and capacity to purchase is necessary for performing the actual behaviour $(\beta=0.054, t=6.814, p<0.05)$

Secondly, the result in table below also demonstrates that government regulation strongly influence intention and consumer buying behaviour $(\beta=0.043, t=2.969, \mathrm{p}<0.05)$. Thirdly, the result demonstrates that Tanzanians consumers have a limitations to purchase pirated music CDs due to influence of self-regulatory efficacy as hypothesis deems to be positive significant to consumer buying behaviour $(\beta=0.054, t=1.448, p<0.05)$. Fourthly, self-regulatory efficacy was also predicted to be positively related to intention (Hypothesis 4 ). The result demonstrated that there is a significant positive relationship between self-regulatory efficacy and intention. $(\beta=0.036, t=15.299, p<0.01)$. The result shows a strong positive association between subjective norm and intention $(\beta=0.047, t-$ 
value $=2.268, \mathrm{p}<0.05)$ and therefore the hypothesis 5 is supported.

Mostly, the insignificant results appears to be unexpected regarding relationship between idolatry and intention. It is surprising because in several contexts, it has been established that idolatry could not stimulate purchases of pirated music CDs as Y generation regards the idols as their friends and the sense of belonging as one-self (Wang et al., 2009). Evidently, variables are mutually exclusive in certain instances the result in this study has demonstrated that. This is an indication that consumers in Tanzania without the influence of level idolatry (higher/lower) in the musicians has the capacity to purchase pirated music CDs $(\beta=0.049, t=0.221, p<0.05)$.

Table 1: Structural Model Assessment with Moderator

\begin{tabular}{|c|c|c|c|c|c|c|}
\hline Нyp & Relationship & Std.Beta & SE & $t$-Value & $P$-Value & Decision \\
\hline $\mathrm{H} 1$ & $\mathrm{INT} \rightarrow \mathrm{CBB}$ & 0.054 & 0.054 & $6.814^{* *}$ & 0.000 & Supported \\
\hline $\mathrm{H}_{2}$ & $\mathrm{INT}^{*} \mathrm{GR} \rightarrow \mathrm{CBB}$ & 0.043 & 0.043 & $2.969^{* *}$ & 0.002 & Supported \\
\hline $\mathrm{H}_{3}$ & $\mathrm{SRE} \rightarrow \mathrm{CBB}$ & 0.054 & 0.054 & $1.448^{* *}$ & 0.074 & Supported \\
\hline $\mathrm{H}_{4}$ & $\mathrm{SRE} \rightarrow \mathrm{INT}$ & 0.036 & 0.036 & $15.299^{* * *}$ & 0.000 & Supported \\
\hline $\mathrm{H}_{5}$ & $\mathrm{SN} \rightarrow \mathrm{INT}$ & 0.047 & 0.047 & $2.268^{* *}$ & 0.012 & Supported \\
\hline H6 & $\mathrm{ID} \rightarrow \mathrm{INT}$ & 0.049 & 0.049 & $0.221^{* *}$ & 0.413 & Not Supported \\
\hline
\end{tabular}

Note: ${ }^{* *}$ Significant at 0.01 (1 tailed), ${ }^{* *}$ Significant at 0.05 (1 tailed), ${ }^{*}$ Significant at 0.1 (1 tailed).

\subsection{Evaluation of Effect Size $\left(f^{2}\right)$}

As indicated in Table 2, the effect sizes for self-regulatory efficacy, subjective norm and idolatry on intention are $0.450,0.013$, and 0.000 respectively. Thus, the effects sizes of these three exogenous constructs on intention can be considered as large, none and none respectively by following Cohen's (1988) recommendation. Furthermore, two constructs in this study, namely self-regulatory efficacy and intention shows the effect size of 0.004 and 0.144 respectively which also according to Cohen's (1988) recommendation, can be considered as none and small effects respectively. Thus, two exogenous constructs in this study, name intention and consumer buying behaviour were seen to contribute moderate and weak $R^{2}$ value (31.7\% and $\left.20.1 \%\right)$ respectively in the endogenous construct.

Table 2: Effect Size on the Endogenous Latent Construct, based on Cohen's (1988) recommendation

\begin{tabular}{lccccc}
\hline R-squared & $\mathbf{R}^{2}$ Incl. & $\mathbf{R}^{2}$ Excl. & $\mathbf{R}^{2}$ incl-R $\mathbf{R}^{2}$ excl & $\mathbf{1}^{-} \mathbf{R}^{2}$ incl & Total Effect \\
\hline Self-regulatory efficacy & 0.324 & 0.020 & 0.304 & 0.676 & 0.450 \\
Subjective norm & 0.324 & 0.315 & 0.009 & 0.676 & 0.013 \\
Idolatry & 0.324 & 0.324 & 0.000 & 0.676 & 0.000 \\
Intention & 0.196 & 0.080 & 0.116 & 0.804 & 0.144 \\
Self-regulatory efficacy & 0.196 & 0.193 & 0.003 & 0.804 & 0.004 \\
\hline
\end{tabular}

\subsection{Testing Moderating Effects}

For the product indicator approach to be applied to test the moderating effects of government regulation on the relationship between intention and consumer buying behaviour. The product terms of the moderating variable is created as well as that of the indicators of the exogenous latent variable (intention and government enforcement and government support). According to Kenny \& Judd, (1984), in the structural model these product terms are then used as indicators of the interaction term. In other words, each indicator of the moderator is multiplied by the mean-centred indicator of the exogenous latent variable. Cohen's, (1988) recommendations is applied to determine the strength of the moderating effects as well as for the estimation of effect sizes. Thus, in Figure 4, the estimates after the application of product indicator approach, (i.e., the product indicator approach for examining the moderating effect of government regulation on the relationship between exogenous 
and endogenous latent variables) has been established. Recall that Hypothesis 2 had earlier proposed that government regulation could moderate the relationship between intention and consumer buying behaviour indicating that the interaction terms representing intention and government regulation ( $\beta$ $=0.043, \mathrm{t}=2.969, \mathrm{p}<0.05)$ was significant statistically. Expectedly, hypothesis 2 was fully supported at o.or level of significance. But the path coefficients in the structural model was also used in plotting the moderating effect of government regulation on the relationship between intention and consumer buying behaviour. Figure 4 below clearly indicated that Government Regulation dampens the positive relationship between Intention and Behaviour. This implies that Government regulation does not moderate the relationship between Tanzanian Generation Y consumer intention to purchase pirated music CDs and actual buying behaviour.

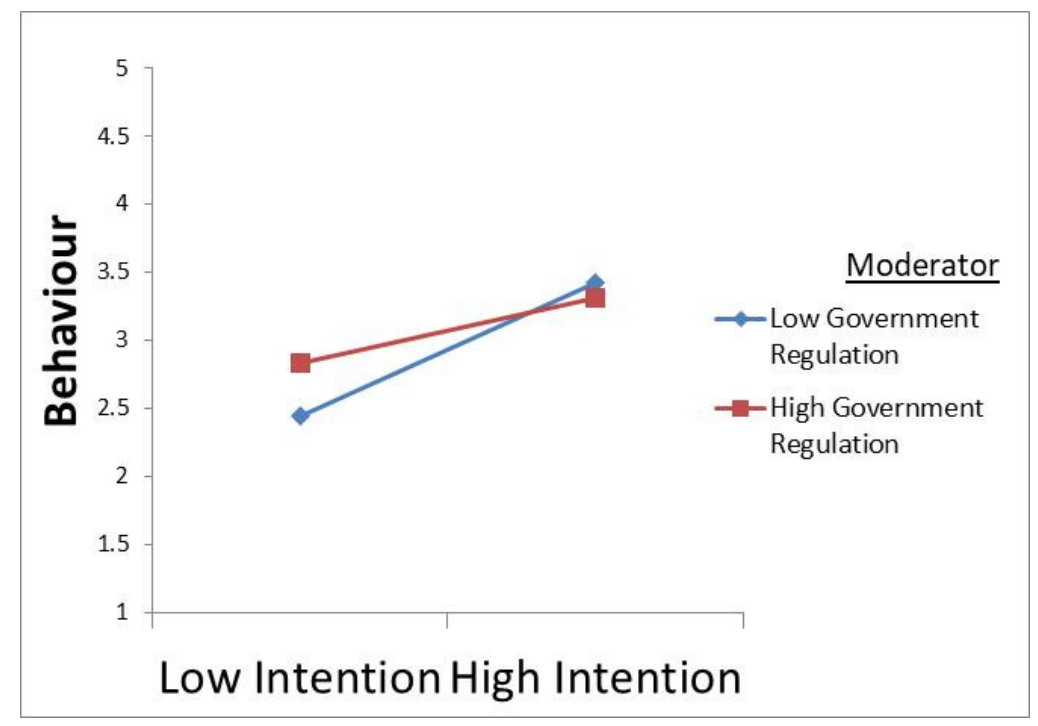

Figure 4: Interaction effects of intention and government regulation on consumer buying behaviour

\subsection{Predictive Relevance of the Model}

The sum of the squared observations (SSO) including the sum of the squared prediction errors (SSE) were obtained in table below. The value of the predictive relevance $Q^{2}$ (1-SSE/SSO) was shown also in the table 3. Thus, the predictive relevance $Q^{2}$ of the endogenous latent variable (consumer buying behaviour and intention) in this path model, has a value of 0.196 and 0.323 respectively, which are above zero. This implies predictive relevance of the model for this constructs (Chin, 1998b; Fornell \& Cha, 1994; Henseler et al., 2009).

Table 3: Construct Cross-Validated Redundancy

\begin{tabular}{lccc}
\hline Total & SSO & SSE & 1-SSE/SSO \\
\hline Consumer Buying Behaviour & 491 & 394.564 & 0.196 \\
Intention & 491 & 332.255 & 0.323 \\
\hline
\end{tabular}

\subsection{Summary of Analysis}

The hypothesized relationships summary of the results in this study are presented in this section. 
Hypotheses $\mathrm{H}_{1}, \mathrm{H}_{2}, \mathrm{H}_{3}$ and $\mathrm{H}_{4}$ and $\mathrm{H}_{5}$ were supported, only $\mathrm{H}_{6}$ was not supported as shown in Table 4 below

Table 4: Summary of Hypotheses Testing

\begin{tabular}{clc}
\hline Hypothesis & Hypothesized Paths & Findings \\
\hline $\mathbf{H 1}$ & Intention $\rightarrow$ Consumer Buying Behaviour & Supported \\
$\mathbf{H}_{\mathbf{2}}$ & Intention ${ }^{\star}$ Government Regulation $\rightarrow$ Consumer Buying Behaviour & Supported \\
$\mathbf{H}_{\mathbf{3}}$ & Self-Regulatory Efficacy $\rightarrow$ Consumer Buying Behaviour & Supported \\
$\mathbf{H}_{\mathbf{4}}$ & Self-Regulatory Efficacy $\rightarrow$ Intention & Supported \\
$\mathbf{H}_{\mathbf{5}}$ & Subjective Norm $\rightarrow$ Intention & Supported \\
$\mathbf{H 6}$ & Idolatry $\rightarrow$ Intention & Not Supported \\
\hline
\end{tabular}

\section{Discussion}

This study investigates purchases of pirated music CDs in Tanzania. Drawing upon existing research from piracy, and marketing, this study empirically examined a model to ascertain those factors that can influence consumers' behaviour by using core variables of TPB and other external factors. In general, the findings from this study provide support for our model. Intention was found to influence consumer purchase behaviour of pirated music CDs. Further, subjective norm was found to be the strongest determinant of intention. However, idolatry has no significant influence on intention in this music CDs piracy setting.

\section{Theoretical and Practical Implications}

This study immensely contributes to research within the confine of consumer purchase behaviour, with a specific of pirated music CDs. In the section that follows, the theoretical and practical implications of the findings are presented

\subsection{Theoretical implications}

First, the study followed a novel research framework modified from Theory of Planned Behaviour (TPB) that was originally proposed by Ajzen (2006) to study purchase behaviour. Past investigations indicated that the model was hardly examined in explaining music piracy behaviour. A systematic literature exploration shows that the model went almost overlooked by music piracy behaviour researchers because it was not meant for explaining music piracy related behaviour. Enormous amount of past publications based on TPB was overwhelmingly linked to music piracy behaviour and digital piracy research. Futher review of literature indicated every possibility of using this model for music piracy behaviour research. The empirical evaluation of the model shows adequate fit statistics with sufficient level of statistical power. Therefore, the current study may have theoretically contributed to the body of knowledge by proposing and empirically examining the modified framework of TPB.

Although subjective norm has been widely studied in music piracy behavior research, the higher order operationalization has been scant as well. Past studies showed a trend of considering only injuctive norm, whereas leaving descriptive norm understudied. Therefore, subjective norm has been viewed as a second order constuct comprising of injuctive and descriptive norms, which appears to be an empirically valid and statistically significant. Therefore, such an operationalization may have theoretically contributed by referring to a complex yet measureable and exhaustive construct of subjective norm. The success of the incorporation of additional external factor specifically related to music idolatry in the TPB model is evident from the results. The results suggest that the proposed extended model of purchases of pirated music CDs demonstrates useful explanatory and predictive 
power (Lin et al., 2015).

\subsection{Practical Implications}

Theoretical contributions and empiricals findings have managerical implications as well. A number of customers insights may emerge that are discussed below.

First, knowing consumers' background provides immense advantage to marketers. Sometimes, segmentation and communication decisions are based on demographic profile of consumers. The study provides a clear demographic profile of who are purchasing pirated music CDs. It appears that Generation Y who purchase pirated music CDs in Tanzania are mostly lower income and selfemployed, predominantly single male with lower education. Majority of studies on pirated music in Tanzania as it may be understood from the literature review were exploratory in nature, hence purchase behaviour and motivation of such behaviour about conclusively infer it is difficult. Understanding behaviour of pirated music consumers as it is expected will shed light on future designing marketing programs, demand estimation, as well as policy issues and discourage of such purchase of pirated music CDs for greater welfares of both music industry and consumers. It confirms with previous studies that reported similar demograpchic profile of pirated music consumers. Such information may immensely help managers in defining market segment, as well as designing and implementing strategy decisions.

Second, understanding the antecedents of intention and predictors of purchase behavior may provide important insights for managers. It appears that antecedents of intention moderately explains the variation intention. Therefore, the influence of antecedents may be strengthened by looking into their components first. For example, it appears that subjective has the highest strength into the intention construct. Therefore, priorities may be set while designing promotional communication. subjective norm appeals may work better to induce purchase intention strength among Tanzania Generation Y. Therefore, managers may act upon this insight, it is better to go for subjective norm appeal when communicating to pirated music CDs users in Tanzania.

According to Kiksen (2012), information may reduce consumers' risk perception depending on the credibility of the information source. As literature shows that friend and family sources are generally more credible than marketing organizations (Solomon, 2004). the influence of subjective norm on intention is quite reasonable. Therefore, managers need to take an integrated approach to handle all these entangled issues of norms and intention in forming consumers' negative intention towards music piracy. The key to such program may lie in creating an overall positive experience for consumers who would ultimately influence the intention of others through social referrals. Importantly, idolatry plays an important role in music acquisition from different channels can be utilized by policymakers to promote antipiracy campaigns using pop/rock music idols as the spoke people on the bad effects of this criminal activity. Therefore, based on the theoretical and practical implications, the study is expected to be useful to future researchers and practitioners alike.

\section{Limitation and Future Research Direction}

The study has some limitations just like any other one. The study was carried out in the city of Dares-salaam while other regions were not taken into consideration. Future researchers can consider more regions in their research as such may help to broad the generalizations of the findings. Aside, consumers of eight shopping malls were investigated, even though this does not affect the generalizability of our findings, future researchers could consider more shopping malls as such will make the research findings to be more robust. Coincidentally, the respondents of this study were relatively generation Y users of pirated music CDs from Tanzania. Recent report has shown that Tanzanian are the highest users of pirated music CDs in East Africa. In view of this, this study can be replicated in other African countries with the purpose of testing the veracity of the model. Additionally, some variables such as subjective Norm (Levin, Dato-on, \& Mamolis, 2007) which have 
been empirically verified by past researchers should be tested further by future researchers. Since this study was carried out on users of pirated music CDs in Tanzania, it will be good if idolatry identification and attachment of fans or idols, and sense of identification felt by the respondents forming favourable usefulness perceptions of the fans club that motivates them and produces their approval or re-purchase behaviour of original music CDs (Wang et al., 2009) is, is tested on level of purchase behaviour of the users. Subjective Norm tests the influence of friends, family and colleagues who are users of pirated music CDs. This therefore indicates that future researchers can test these variables on potential users of music CDs in Tanzania since evidence has shown that we still have many risk averters who will still use this pirated music CDs because they believe it is still not full of risk. Testing these variables will help to predict factor that can help to reduce the risk averters to embrace the music platform in the nearest future.

\section{Conclusions}

This study based on the overall research findings has been able to provide the moderating role of government regulation on the relationship between intention and consumer buying behaviour and also additional evidence to the growing body of knowledge. This study results has been able to support the key theoretical propositions. Particularly, all of the research questions posed it has successfully responded and regardless of some limitations also addressed all the formulated objectives. With regards to the six hypotheses formulated in this study, out of the five direct hypotheses that examine the relationships between self-regulatory efficacy, subjective norm and idolatry, only one (idolatry and purchase intention relationship) was negatively significant. While the moderating paths are statistically significant and supported.

Firstly, the purpose of this study is to examine the factors influencing consumer behaviour in purchasing pirated music CDs in Tanzania Mainland. The finding of the study indicates that the level of consumer intention to purchase pirated music CDs of the designated respondents is moderate. This means that the level to which existing consumers positively encourage and recommend the purchase of pirated music CDs to others is moderate, and is dedicated to their re-patronizing their preferred pirated channels. This finding is considered as an addition to the body of knowledge linking to the importance of higher levels of consumer intention to purchase pirated music CDs in the music industry. It also suggests that the managers of the music industry should employ more persuasive strategies on consumer buying behaviour, since the intention is not necessarily being the actual behaviour. Findings of the study also suggest that two factors: self-regulatory efficacy, subjective norm have significant influence on purchase intention and intention and self-regulatory efficacy have positive significant influence in consumer buying behaviour, while idolatry has insignificant influence on purchase intention. The finding avails managers and academicians a much stronger basis for recommending strategies to ensure high level of consumer buying behaviour. Therefore, it is imperative that music industry should take extra effort to improve self-regulatory efficacy, subjective norm particularly idolatry level in their efforts to attain higher level of consumer buying intention.

Despite the fact that many studies have examined several underlying factors to consumer buying behaviour among Generation Y, however, the present study has addressed a theoretical gap by incorporating government regulation as a non-significant moderating variable. This present study has also provided theoretical and empirical non-support for the moderating role of government regulation on the relationship between intention and consumer buying behaviour. And it has also endeavour to estimate how government regulation theoretically couldn't moderates the relationships between the exogenous latent variables and the endogenous latent variable. Over again, this study's theoretical framework was also able to add to the domain of consumer buying behaviour for change and Theory of Planned Behaviour (TPB) by examining the influence of intention on consumer buying behaviour as well as the effect of intention factors on consumer buying behaviour. In addition to this theoretical contributions, the results from this study has also provided some important practical implications to music industry and other music stakeholders. The study also demonstrated that TPB 
is a feasible theory to explain and predict behaviour intention and purchase behaviour of pirated music CDs of Y-Generation consumers in Tanzania. Moreover, regarding this study's limitations, several future research directions has been suggested.

In conclusion, according to Hart, (1998 p. 24) all the relevant originality requirements of a doctoral thesis has been able to meet in this study. These requirements are: firstly, this study has not been carried out earlier and is an empirical-based research. Secondly, known ideas and practices already established this study utilised but different and new interpretations imbibed. Thirdly, the present study was able to lay new suggestion to bear on the concept of consumer buying behaviour in Tanzania music industry. Fourthly, the study discovers new dimension to idolatry that scholars in music industry have not considered earlier.

\section{Reference}

Ajzen, I., \& Fishbein, M. (1980). Understanding attitudes and predicting social behavior. englewood cliffs, nj: prentice-hall, inc.

Ajzen, Icek. (1985). From intentions to actions: A theory of planned behav- ior. In Action control: From cognition to behavior, edited by J. Kuhl and J. Beckman, 11-39. Berlin: Springer-Verlag.

Ajzen, Icek. (2006). Constructing a theory of planned behavior questionnaire. Biofeedback and Selfregulation, 17, 17. https://doi.org/10.1016/0749-5978(91)90020-T

Arli, D., Tjiptono, F., \& Porto, R. (2015). The impact of moral equity, relativism and attitude on individuals' digital piracy behaviour in a developing country. Marketing Intelligence \& Planning, 33(3), 1-29.

Bashir, S., Phau, I., \& Ferguson, G. (2012). Exploring the role of theory of planned behaviour in music piracy. Espace.Library.Curtin.Edu.Au.

Baumeister, R. F., Sparks, E. a., Stillman, T. F., \& Vohs, K. D. (2008). Free will in consumer behavior: Self-control, ego depletion, and choice. Journal of Consumer Psychology, 18(1), 4-13. https://doi.org/10.1016/j.jcps.2007.10.002

Bikoff, J. L., Heasley, D. K., Sherman, V., \& Stipelman, J. (2015). Fake it 'til we make it: regulating dangerous counterfeit goods. Journal of Intellectual Property Law $\mathcal{E}$ Practice, 10(4), 246-254. https://doi.org/10.1093/jiplp/jpvo16

Blake, R. H., \& Kyper, E. S. (2013). An investigation of the intention to share media files over peer-to-peer networks. Behaviour \& Information Technology, 32(4), 1-13. https://doi.org/10.108o/o144929X.2011.558591

Buitrago, P. F., \& Mo, A. (2009). A Tanzania for the Creatives: Opportunities and Challenges for Tanzania's Creative Industries. Dar es Salaam: British Council (Unpublished).

Caprara, G. V., Regalia, C., \& Bandura, A. (2002). Longitudinal impact of perceived self-regulatory efficacy on violent conduct. European Psychologist, 7(1), 63-69. https://doi.org/10.1027//1016-9040.7.1.63

Charron, J. P. (2015). Music, movie, and software piracy: explaining downloaders' compensation dilemma and exploring factors influencing online payment behaviors from a cognitive dissonance perspective.

Chin, W. W. (1998). The partial least squares approach to structural equation modeling. modern methods for business research, G. A. Marcoulides (ed.), Lawrence Erlbaum Associates, Mahwah, NJ, 1998 .

Chin, W. W., Marcolin, B. L., \& Newsted, P. R. (2003). A partial least squares latent variable modelling approach for measuring interaction effects: results from a monte carlo simulation study and an electronic mail emotion/adoption study. information system.

Chiou, J. S., Huang, C. Y., \& Lee, H. H. (2005). The antecedents of music piracy attitudes and intentions. Journal of Business Ethics, 57, 161-174. https://doi.org/10.1007/s10551-004-5263-6

Cohen, J. (1988). Statistical power analysis for the behavioral sciences (2nd ed.). hillsdale, nj: lawrence erlbaum associates, inc.

Coyle, J. R., Gould, S. J., Gupta, P., \& Gupta, R. (2009). “To buy or to pirate”: the matrix of music consumers' acquisition-mode decision-making. Journal of Business Research, 62(10), 1031-1037. https://doi.org/10.1016/j.jbusres.2008.05.002

Cronan, T. P., \& Al-Rafee, S. (2008). Factors that influence the intention to pirate software and media. Journal of Business Ethics, 78, 527-545. https://doi.org/10.1007/s10551-007-9366-8

Cuadrado, M., Miquel, M. J., \& Montoro, J. D. (2009). Consumer attitudes towards music piracy: a spanish case study. International Journal of Arts Management, 11(3), 4-15.

d'Astous, A., Colbert, F., \& Montpetit, D. (2005). Music piracy on the web - how effective are anti-piracy arguments? evidence from the theory of planned behaviour. Journal of Consumer Policy, 28, 289-310. https://doi.org/10.1007/s10603-005-8489-5 
Einerson, M. . (1998). Fame, fortune, and failure young girls' moral language surrounding popular culture. Youth $\mathcal{E}$ Society, 30, 241-257.

Eisenberg, A. J., \& Dhabi, N. . (2015). Digital technology and the music recording industry in nairobi, kenya, (October 2015), 1-18.

Fetscherin, M. (2009). Importance of cultural and risk aspects in music piacy: a cross-national comparison among university students. Journal of Electronic Commerce Research, 10, 42-55. Retrieved from http://www.csulb.edu/journals/jecr/issues/20091/Paper4.pdf

Fornell, C., \& Cha, J. (1994). Partial least squares. Advanced Methods of Marketing Research, 407, 52-78.

Hair, J. F., Sarstedt, M., Ringle, C. M., \& Mena, J. A. (2012). An assessment of the use of partial least squares structural equation modeling in marketing research. Journal of the Academy of Marketing Science, . 40, .

Hair, J. F., Hult, G. T. M., Ringle, C. M., \& Sarstedt, M. (2014). A primer on partial least squares structural equation modeling (pls-sem). thousand oaks: Sage Publications.

Hair, J. F., Ringle, C. M., \& Sarstedt. (2011). Pls-sem: indeed a silver bullet. Journal of Marketing Theory and Practice, 19, 139-152.

Halttunen, V., Makkonen, M., \& Frank, L. (2010). Indifferent behaviour of young digital content consumers - an interview study. Lnformation Assurance and Security Letters, 1, 66-71.

Hardy, W., Krawcyzyk, M., \& Tyrowicz, J. (2013). Why is online piracy ethically different from theft? a vignette experiment.

Hart, C. (1998). Doing a literature review: releasing the social science research imagination. london: sage publications.

Henseler, J., \& Fassott, G. (2010). Testing moderating effects in pls path models: an illustration of available procedures handbook of partial least squares : Springer.

Henseler, J., Ringle, C. M., \& Sinkovics, R. R. (2009). The use of partial leasts squares path modeling in international marketing. in r. r. sinkovics \& p. n. ghauri (eds.) bingley: emerald. Advances in International Marketing, 20, 277-320.

Huang, Y.-A., Lin, C., Su, H., \& Tung, M.-L. (2015). I worship , so i download ? idol worship , music purchase and piracy by young consumers in taiwan. Asia Pacific Journal of Marketing and Logistics, 27(1), 1-58.

Hyman, M. R., \& Sierra, J. J. (2010). Idolizing sport celebrities: a gateway to psychopathology? Young Consumers: Insight and Ideas for Responsible Marketers, 11(3), 226-238. https://doi.org/10.1108/17473611011074296

Jesse, T. (2015). Factors determining the intention to obtain music legally. A quantitative research approaching the contemporary behaviour of consumers toward the legal acquisition of music in Sweden.

Kajiru, E. (2009). The potential of the contribute to national economy and development in tanzania.

Kenny, D. A., \& Judd, C. M. (1984). Estimating the nonlinear and interactive effects of latent variables. psychological bulletin, (96), 201-210.

Khadka, I. (2015). Software piracy: a study of causes, effects and preventive measures. Retrieved from http://theseus.fi/bitstream/handle/10024/87274/Khadka_Ishwor.pdf?sequence=1

Kiksen, C. (2012). Behavioural insights into music piracy.

Kura, K. M., Shamsudin, F. M., \& Chauhan, A. (2014). Mediating role of self-regulatory efficacy on the relationship between punishment certainty, punishment severity and organizational deviance. Management Science Letters, 4(4), 651-658. https://doi.org/10.5267/j.msl.2014.2.029

Lapinski, M. K., \& Rimal, R. N. (2005). An explication of social norms. Communication Theory, 15(2), 127-147. https://doi.org/10.1093/ct/15.2.127

LaRose, R., \& Kim, J. (2007). Share, steal, or buy? a social cognitive perspective of music downloading. Cyberpsychology \& Behavior, 10(2), 267-277. https://doi.org/10.1089/cpb.2006.9959

Larose, R., Mastro, D., \& Eastin, M. S. (2001). Understanding internet usage: a social-cognitive approach to uses and gratifications. Social Science Computer Review, 19, 395-413. https://doi.org/10.1177/089443930101900401

Levin, A., Dato-on, M., \& Mamolis, C. (2007). Deterring illegal downloading: the effects of threat appeals, past behavior, subjective norms, and attributions of harm. Journal of Consumer Behaviour, 6, 111-122. https://doi.org/10.1002/cb

Li, H., Miller, K., \& Ruiz, S. (2014). Effects of music therapy and piano lesson on academic achievement , classroom behaviors, and self-esteem of at- risk students : a pilot study. International Journal of Music, 1(1), 30-37. https://doi.org/10.5176/oooo-0oo5

Lin, T., Hsu, J., \& Chen, H. (2013). Customer willingness to pay for online Music: the role of free mentality. Journal of Electronic Commerce Research, 104(4), 315-333. Retrieved from http://web.csulb.edu/journals/jecr/issues /20134/Paper3.pdf

Lin, X., Zeng, D., Cheng, L., \& Wang, J. (2015). Study on the influence factors of music piracy in China based on sem model. In ieeexplore.ieee.org (pp. 1-6). Retrieved from http://www.scientific.net/KEM.364-366.903 
Makulilo, A., \& Boshe, P. (2013). Looks like copyright license but really it is not ' -cosata and enforcement of copyright in tanzania. Open University Law Journal, 4(2), 120-132.

Mushi, H. M. (2016). Modelling Pirated Music Compact Discs (CDs) Purchase Behaviour In Tanzania Mainland. Singaporean Journal of Business Economics, and Management Studies, 4(10), 7-15.

Nova, F., Rahayu, D., \& Handayani, E. (2015). The influence of consumer moral, risk perception, and consumer motive to consumer buying intention of pirated cds/dvds. International Journal of Education and Research, 3(9), 427-438.

Oaten, M., \& Cheng, K. (2006). Longitudinal gains in self-regulation from regular physical exercise. British Journal of Health Psychology, 11, 717-733. https://doi.org/10.1348/135910706X96481

Ouellet, J. F. (2007). The purchase versus illegal download of music by consumers: the influence of consumer response towards the artist and music. Canadian Journal of Administrative Sciences, 24(2), 107-119. https://doi.org/10.1002/cjas.16

Plowman, S., \& Goode, S. (2009). Factors affecting the intention to download music: quality perceptions and downloading intensity. Journal of Computer Information Systems, 49(4), 84-97.

Raviv, A. D., Bar-Tal, A., Raviv, \& Ben-Horin, A. (1996). Adolescent idolization of pop singers: causes, expressions, and reliance. Journal of Youth and Ado- Lescence, 25(5), 631-650.

Reardon, S. A., Reardon, J., \& Vida, I. (2012). Consumer decision model of intellectual property theft in emerging markets. Organizations and Markets in Emerging Economies, 3(1), 58-74.

Ringle, C. M., Wende, S., \& Will, A. (2005). Smartpls 2.o. retrieved nov. 25, 2014 from www.smartpls.de.

Setiawan, B., \& Tjiptono, F. (2013). Determinants of consumer intention to pirate digital products. International Journal of Marketing Studies, 5(3), 48-55. https://doi.org/10.5539/ijms.v5n3p48

Shule, V. (2010). Creative industries: a contributing factor in the revival of tanzania economy.

Solomon, M. R. (2004). Consumer behavior. buying, having, and being (6th ed.). Upper Saddle River, NJ: Pearson Prentice Hall.

Sultan, A. J., Joireman, J., \& Sprott, D. E. (2012). Building consumer self-control: the effect of self-control exercises on impulse buying urges. Marketing Letters, 23, 61-72. https://doi.org/10.1007/s11002-011-9135-4

Tat, F. yik, Boon, G. S., Yi, N. X., \& Chuan, Y. Y. (2012). Factors determining consumer purchasing behaviour of pirated media.

Van Belle, J. P., Macdonald, B., \& Wilson, D. (2014). Determinants of digital piracy among youth in south africa. Communications of the IIMA, 7(3), 47-64.

Vohs, K. D., \& Faber, R. J. (2007). Spent resources: self-regulatory resource availability affects impulse buying. Journal of Consumer Research, 33(4), 537-547. https://doi.org/10.1086/510228

Waldfogel, J. (2012). Music piracy and its effects on demand, supply, and welfare. Innovation Policy and the Economy, 12(1), 91-110.

Wang, C. C., Chen, C.-T., Yang, S.-C., \& Farn, C.-K. (2009). Pirate or buy? the moderating effect of idolatry. Journal of Business Ethics, 9o, 81-93. https://doi.org/10.1007/s10551-009-0027-y

Yue, X. D., Cheung, C. K., \& Wong, D. S. W. (2010). From glamour-oriented idolatry to achievement-oriented idolatry: A framing experiment among adolescents in Hong Kong and Shenzhen. Asian Journal of Social Psychology, 13, 1-8. https://doi.org/10.1111/j.1467-839X.2010.01295.x 